\title{
Geographical dissemination of trace and major elements in honey
}

\author{
Z. Vincevica-Gaile, M. Klavins, V. Rudovica \& A. Viksna \\ University of Latvia, Latvia
}

\begin{abstract}
Honey is a natural food commodity that contains up to 200 components. Within the context of environmental science and considering food safety issues, a relatively simple way for honey differentiation is the quantitative analysis of trace and major elements, especially due to the fact that honey composition is not constant and equal in different geographical locations. Also, considerable influence of botanical origin should be taken into account. The aim of the study was to find out the geographical dissemination of elements in honey by analyzing 80 honey samples collected over the territory of Latvia. Honey samples were collected within two seasons (2009/2010). Water based acidified solutions of honey samples were analyzed by atomic absorption spectrometry (AAS) and inductively coupled plasma mass spectrometry (ICP-MS). It was possible to quantify 5 major elements $(\mathrm{Ca}, \mathrm{Fe}, \mathrm{K}, \mathrm{Mg}, \mathrm{Na})$ and 15 trace elements (Al, As, Ba, Cd, Co, Cr, Cu, Mn, Mo, Ni, Pb, Rb, Sr, V, Zn). Results showed slight differences between the selected regions taking into account that the region selection was based on the available geochemical information. Some regional distinctions were detected in element content of honey, mainly concerning heavy metals. Comparison of results with the data from other countries revealed that honey samples from Latvia can be assessed as medium rich with major elements as well as slightly contaminated with potentially toxic elements. It was determined that the element content of honey is not strongly connected with geochemical background but more is influenced by the consequences of anthropogenic activities.

Keywords: food analysis, honey, trace elements, major elements, quantitative analysis, environmental impact, Latvia.
\end{abstract}




\section{Introduction}

Honey is natural food commodity with complicated chemical composition that contains up to 200 components (Silva et al. [1]) among which the greatest part takes monosaccharides (glucose and fructose up to $65-75 \%$, and other sugars), followed by water (15-20\%) (Enrich et al. [2]) and other valuable ingredients, such as proteins, amino acids, ferments, hormones, organic acids, vitamins, flavonoids, pigments, minerals, pollen and wax particles (Ajtony et al. [3]). Within the context of environmental science and considering food safety issues relatively simple way for honey differentiation is quantitative analysis of trace and major elements, especially due to the fact that honey composition is not constant and equal in different geographical locations. Levels of major and trace elements in honey in great extent are influenced by such site specific factors as environmental pollution or geological background (Anklam [4]). Also considerable influence of botanical origin should be taken into account but it is not the target discussion issue in this article.

Mineral content of honey is quite variable - this substance, produced by honey bees Apis mellifera, may contain from about $0.04 \%$ up to $0.2 \%$ of major and trace elements and the amount of minerals can be associated with the colour of honey, respectively pale honey contains lower trace and major element amount than dark honey (Anklam [4]). Amount of major elements (Ca, Fe, K, $\mathrm{Mg}, \mathrm{Na}$ ) in honey is more dependent on natural geographical features at the place of apiaries. The same can be asserted concerning some trace elements, e.g. Mn, $\mathrm{Rb}, \mathrm{V}$ [5-7], while amount of potentially toxic trace elements, such as $\mathrm{Cd}, \mathrm{Cr}$, $\mathrm{Pb}, \mathrm{Zn}$, in honey samples varies due to the anthropogenic activities. Presence of rare elements ( $\mathrm{Ta}, \mathrm{Th}, \mathrm{U}, \mathrm{Ce}, \mathrm{La})$ in honey rather purports influence of specific geological peculiarities (Pisani et al. [8]).

It is widely known that honey composition is strongly connected with its botanical origin but other influences are not studied so deep. Therefore the aim of the study was to find out the geographical dissemination of elements in honey by quantitative analysis of honey samples collected over the territory of Latvia, the country in East Europe. Due to the fact that agriculture and industry have been diminished over a period after the Latvia regained its independency in 1991 and environmental conditions have been improved, it is foreseen that honey produced in Latvia may become a competitive product within the European market of healthy foodstuffs. Knowledge about the dissemination of trace and major elements in honey is important issue within the food science because honey widely is used as natural daily diet supplement and should be not only valuable but also safe for human health.

\section{Materials and methods}

\subsection{Sampling}

Within the current study in total 80 honey samples were collected over all the territory of Latvia in a period of two seasons (2009 and 2010). Collected honey 
samples were grouped in sets based on the geological information of Latvia as shown in fig. 1. Geographical and botanical origination of 78 samples was identified taking into account the available information at the purchasing but 2 honey samples were obtained in supermarkets and therefore their origin is unknown. Honey samples were purchased directly from bee-keepers or at food shops and markets. All the equipment used for honey sample collection and storage excluded any metal tools. Honey samples mostly were poured into plastic containers with tight plastic covers, only some samples were obtained in glass vessels. Until analysis all collected honey samples were stored in a cool and dark place.

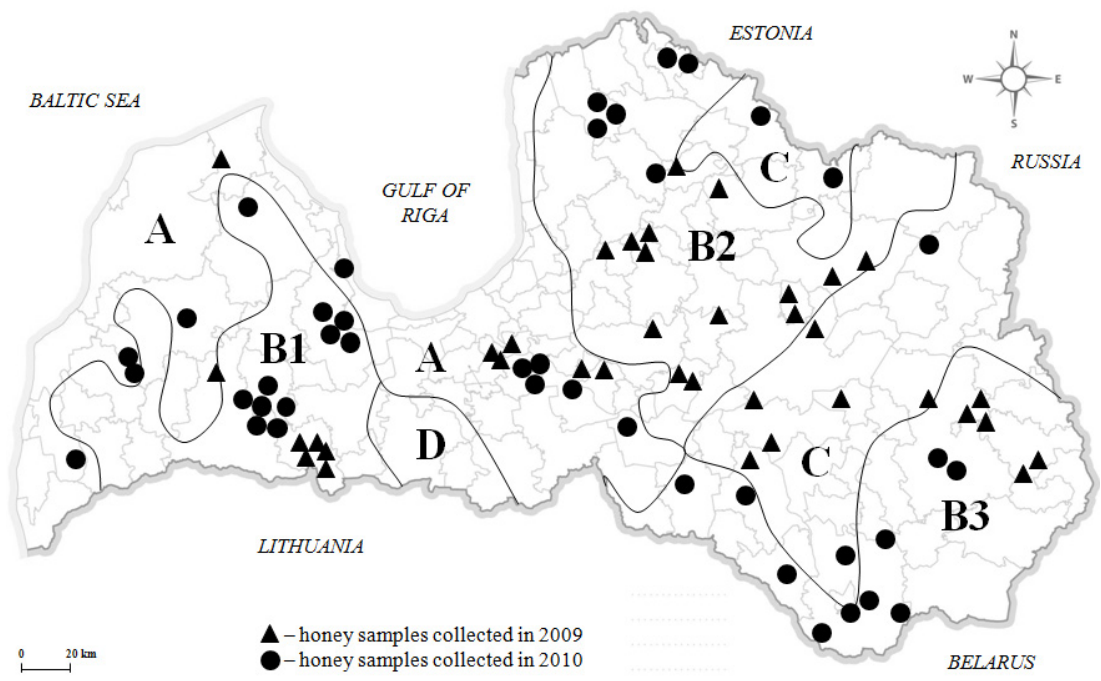

Figure 1: Schematic map of Latvia with the places of geographical origin of collected honey samples within the regions selected by dominant parent soil grading composition and soil type: A - sandy/typical podzol and glay; B - sandy loam and loam sandy/podzol and pseudoglay (B1), erodated podzol and glay (B2, B3); C - mix of clay, peat or sandy loam/podzol and pseudoglay; D - clay/carbonated soil.

\subsection{Sample pretreatment}

Difficulties that can arise within the quantitative analysis of honey are tightly connected with honey as complicated biological matrix that may influence performance of sensitive analytical techniques especially due to the high concentration of carbohydrates. Therefore honey sample preparation prior analysis is very important. One of the ways how to avoid the possible problems consists of honey dissolution in acidic medium (Chudzinska and Baralkiewicz [9], Stankovska et al. [10]). 
Pretreatment of collected honey samples was performed in several modes to find out the most appropriate sample processing way. It is known that matrix of honey should be cleaved therefore such sample preparation method as wet digestion by concentrated acid with or without microwave influence is described in literature (e.g. Silici et al. [11]) and is widely applied for decomposition of environmental and biological samples. According to this, an experimental honey sample was diluted in analytically pure concentrated nitric acid with adding concentrated hydrogen peroxide, followed by heating at $160^{\circ} \mathrm{C}$ until nitrogen oxides were vaporised. However, this method is time consuming, expensive and environmentally unfriendly. Another pretreatment method tested was the dry ashing of honey samples followed by ash dissolution in concentrated analytically pure nitric acid as suggested by Yarsan et al. [12]. This mode of honey pretreatment was dismissed due to the inaccuracy of obtained analytical results. Taking into account results of experimental sample preparation, as well as defined requirements for sample preparation such as accuracy, gain of time, less labour-consumption and cheapness, it was decided to make pretreatment of honey samples by diluting in warm deionised water similarly as described by Staniskiene et al. [13]. Final honey sample pretreatment was implemented as follows: a) precise mass of honey $(0.5000 \pm 0.0020 \mathrm{~g})$ was weighted on analytical scales; b) $50 \mathrm{ml}$ of warmed-up deionised ultra pure water were added; c) water solution was acidified by $0.2 \mathrm{ml}$ analytically pure concentrated nitric acid. After such honey sample pretreatment obtained analytical results were similar to those obtained after sample preparation using wet digestion that makes no sense to apply expensive and complicated techniques. All the pretreatment procedure was carried out for triplicates of every single honey sample.

\subsection{Applied analytical methods}

Analytical methods used most frequently for quantitative element detection in honey are based on spectroscopy and mass spectrometry methodologies, such as inductively coupled plasma atomic emission spectrometry (ICP-AES), atomic absorption spectrometry (AAS) and total reflection X-ray fluorescence spectrometry (TXRF). Methods based on atomic absorption, e.g. AAS, flame atomic absorption spectrometry (FAAS) and flame atomic absorption spectrometry on graphite furnace (GFAAS) are widely used in honey analysis (e.g. Madejczyk and Baralkiewicz [5], Lachman et al. [14]). The main requirements for analytical techniques applied for trace and major element quantification in honey or other biological samples are accuracy, selectivity and high level of certainty (Ajtony et al. [3]).

Analytical methods chosen for the current study was atomic absorption spectrometry on graphite furnace (GFAAS), atomic absorption spectrometry in flame (FAAS) for major element quantification using "PerkinElmer AAnalyst 200" spectrometer and inductively coupled plasma mass spectrometry (ICP-MS) for trace element quantification using "Thermoelectronic" ICP-MS apparatus. All the analyses were performed in the laboratories of the University of Latvia. 


\section{Results and discussion}

\subsection{Trace elements in honey}

It was possible to detect quantitative amounts of 15 trace elements in honey samples from Latvia. Comparison of average values revealed following sequence of trace elements counting from the smallest: $\mathrm{V}$, As, $\mathrm{Mo}, \mathrm{Cd}, \mathrm{Co}, \mathrm{Pb}, \mathrm{Cr}, \mathrm{Ni}, \mathrm{Ba}$, $\mathrm{Sr}, \mathrm{Cu}, \mathrm{Al}, \mathrm{Rb}, \mathrm{Zn}$ and $\mathrm{Mn}$. Precise amounts of elements are listed in table 1 but information about amounts of $\mathrm{Cd}, \mathrm{Cr}, \mathrm{Ni}$ and $\mathrm{Pb}$ can be found in table 2 .

Table 1: $\quad$ Trace element content of honey samples from Latvia.

\begin{tabular}{|c|c|c|c|c|c|c|c|}
\hline \multirow{2}{*}{$\begin{array}{l}\text { Trace } \\
\text { element }\end{array}$} & \multicolumn{3}{|c|}{ Calculated value $(\mu \mathrm{g} / \mathrm{kg})$} & \multirow{2}{*}{$\begin{array}{c}\text { Trace } \\
\text { element }\end{array}$} & \multicolumn{3}{|c|}{ Calculated value $(\mu \mathrm{g} / \mathrm{kg})$} \\
\hline & Min & Max & Average & & Min & Max & Average \\
\hline $\mathrm{Al}$ & 88.26 & 2653.76 & 444.63 & Mo & 0.28 & 35.34 & 7.41 \\
\hline As & 1.13 & 80.57 & 4.15 & $\mathrm{Rb}$ & 174.15 & 9429.76 & 1335.23 \\
\hline $\mathrm{Ba}$ & 10.94 & 540.71 & 95.84 & $\mathrm{Sr}$ & 32.36 & 1216.63 & 114.13 \\
\hline Co & 4.70 & 122.03 & 10.84 & V & 0.09 & 3.40 & 1.46 \\
\hline $\mathrm{Cu}$ & 59.41 & 1432.71 & 275.65 & $\mathrm{Zn}$ & 150.71 & 18894.01 & 1572.57 \\
\hline $\mathrm{Mn}$ & 75.20 & 13584.36 & 2435.63 & & & & \\
\hline
\end{tabular}

Table 2: $\quad$ Range of potentially toxic trace element content of honey from Latvia and some other European countries.

\begin{tabular}{|c|c|c|c|c|c|}
\hline \multirow{2}{*}{ Country } & \multicolumn{4}{|c|}{ Min-max concentration $(\mu \mathrm{g} / \mathrm{kg})$} & \multirow{2}{*}{ Ref. } \\
\cline { 2 - 6 } & $\mathrm{Cd}$ & $\mathrm{Cr}$ & $\mathrm{Ni}$ & $\mathrm{Pb}$ & \\
\hline $\begin{array}{c}\text { Czech } \\
\text { Republic }\end{array}$ & $1.6-19.3$ & - & $60.0-1530.0$ & $42.0-96.0$ & {$[14,20]$} \\
\hline Hungary & $0.8-3.3$ & $1.8-109.0$ & - & $12.0-163.0$ & {$[3]$} \\
\hline Italy & $1.0-305.0$ & $<2.0-54.0$ & $<50.0-2760.0$ & $28.2-620.0$ & {$[8,17]$} \\
\hline Latvia & $\begin{array}{c}1.91-150.05 \\
(\text { average 8.26) }\end{array}$ & $\begin{array}{c}15.74-313.78 \\
\text { (average } \\
37.46)\end{array}$ & $\begin{array}{c}30.18-514.18 \\
\text { (average } \\
56.61)\end{array}$ & $\begin{array}{c}0.04-147.25 \\
\text { (average } \\
25.02)\end{array}$ & $\begin{array}{c}\text { current } \\
\text { study }\end{array}$ \\
\hline Lithuania & $1.0-14.6$ & $200.0-344.0$ & $206.0-350.0$ & $2.9-189.0$ & {$[7,19]$} \\
\hline Poland & $\begin{array}{c}<1.0(\mathrm{LOD})- \\
103.0\end{array}$ & $5.1-93.0$ & $10.0-1870.0$ & $\begin{array}{c}<1.0(\mathrm{LOD})- \\
9200.0\end{array}$ & {$[9,5]$} \\
\hline Slovenia & - & $110.0-33800.0$ & $0-12700.0$ & $210.0-79100.0$ & {$[16]$} \\
\hline Switzerland & $<1.0-26.0$ & $<1.0-37.0$ & $<1.0-1966.0$ & $3.0-329.0$ & {$[6]$} \\
\hline
\end{tabular}

Using correlation matrix strong correlation $(>0.7)$ was detected between some trace elements: $\mathrm{Al}$ and $\mathrm{V}, \mathrm{Sr}, \mathrm{As} ; \mathrm{Mn}$ and $\mathrm{Rb} ; \mathrm{Sr}$ and $\mathrm{As} ; \mathrm{Ba}$ and $\mathrm{Rb}$.

Trace element analysis is important not only for essential trace element quantitative detection but also for identification of potentially toxic elements such as heavy metals. Dangerous elements for human health are heavy metals e.g. cadmium, cobalt, copper, lead. Presence of heavy metals in honey mostly indicates impact of environmental pollution or consequences of anthropogenic activities, such as use of agrochemicals or transport outflows (Ajtony et al. [3]). Cadmium and lead can be contaminants at bee feeding areas but also it is 
possible that these and other heavy metals can contaminate honey directly from air as dust particles. Potentially toxic trace elements in Latvian honey samples are detected with wide variety but in overall results are not the highest if compared with data from other European countries. Information about differences of $\mathrm{Cd}, \mathrm{Cr}, \mathrm{Ni}$ and $\mathrm{Pb}$ in some countries is summarized in table 2.

Although Co, Cr, Mn, Mo, Zn, V and some other are essential trace elements for humans, they can contaminate honey and can become potentially dangerous for human health if consumed in higher dosages. There are not many literature sources that describe so wide range of trace elements quantified in honey. For example, aluminium have been detected in honey samples from Czech Republic and Poland in exaggerated amounts if compared with obtained data from Latvia, respectively, up to $20.2 \mathrm{mg} / \mathrm{kg}$ [14] and $46.7 \mathrm{mg} / \mathrm{kg}$ [9], while cobalt have been detected in lesser concentrations $-10-87 \mu \mathrm{g} / \mathrm{kg}$ in honey from Greece [15] and $1.6-56.6 \mu \mathrm{g} / \mathrm{kg}$ in Italian honey [8]. Content of copper in honey is very variable from tiny amounts in samples from Hungary $(0.04-0.45 \mathrm{mg} / \mathrm{kg})$ [3] up to considerable amounts in honey from Slovenia $(0.37-15.50 \mathrm{mg} / \mathrm{kg})[16]$.

Similar wide variability of element content of honey refers also to zinc that have been detected in samples from Switzerland, Italy, Czech Republic and Spain around $3-5 \mathrm{mg} / \mathrm{kg}[6,8,14,18]$, whereas in honey from Lithuania and Poland amount of zinc reached $41.25 \mathrm{mg} / \mathrm{kg}$ [19] and $39.7 \mathrm{mg} / \mathrm{kg}$ [9], respectively. Strontium amount in European honey is comparable with the obtained results. Less content of strontium contained Lithuanian honey (19.5$240.9 \mu \mathrm{g} / \mathrm{kg}$ ) [7] but the highest amounts detected in honey from Italy (850$2010 \mu \mathrm{g} / \mathrm{kg})[8]$ and Slovenia $(730-1760 \mu \mathrm{g} / \mathrm{kg})[16]$.

Such rare trace elements as $\mathrm{As}, \mathrm{Mo}, \mathrm{Rb}$ and $\mathrm{V}$ have not been in the centre of attention while analysing honey. The information can be found about levels of arsenic in honey from Italy $(2.8-20.2 \mu \mathrm{g} / \mathrm{kg})$ [8], Hungary $(0-13 \mu \mathrm{g} / \mathrm{kg})$ [3] and Slovenia (1240-1490 $\mu \mathrm{g} / \mathrm{kg})$ [16] and the latter result obviously show evidence of honey contamination. Rubidium has been detected in honey just by Lithuanian researchers at level 193-2447 $\mu \mathrm{g} / \mathrm{kg}$ [7].

In overall, trace element content of honey is more dependent on non natural sources such as anthropogenic activities or environmental pollution, as well contamination during processing and storage of honey. Honey can be polluted by potentially toxic trace elements also via nectar or pollen directly and from contaminated plants which have absorbed unwanted elements from soil, water and air during their physiological development. Bees can also contaminate honey by heavy metal dust particles that can be accumulated on their bodies from environment.

\subsection{Major elements in honey}

Most abundant major elements in honey samples collected in Latvia are potassium and calcium, followed by sodium, magnesium and iron. Quantified potassium content on average is $771.95 \mathrm{mg} / \mathrm{kg}(160.84-2313.50 \mathrm{mg} / \mathrm{kg})$ that can be assessed as middle ratio if compared with data from honey analysis in other European countries where $\mathrm{K}$ content have been detected even more than $4000 \mathrm{mg} / \mathrm{kg}$ in Italian, Polish and Slovenian honey $[8,9,16]$. Calcium amount in 
Latvian honey varies from $17.10 \mathrm{mg} / \mathrm{kg}$ to $271.96 \mathrm{mg} / \mathrm{kg}$ with average value $62.55 \mathrm{mg} / \mathrm{kg}$ but more variable numbers have been found in honey samples from Italy (9.1-409.0 mg/kg) [8] and Spain (42.59-341.00 mg/kg) [20], as described in literature. Sodium and magnesium amounts in Latvian honey are comparable and have been detected on average $\mathrm{Na} 25.18 \mathrm{mg} / \mathrm{kg}(4.05-285.35 \mathrm{mg} / \mathrm{kg})$ and $\mathrm{Mg}$ $22.65 \mathrm{mg} / \mathrm{kg}(7.27-95.31 \mathrm{mg} / \mathrm{kg})$. While in Polish honey range of sodium is only $0.38-89.60 \mathrm{mg} / \mathrm{kg}[5]$, the honey samples from Portugal contain much higher amount of $\mathrm{Na}-90.22-727.79 \mathrm{mg} / \mathrm{kg}$ [1], but the highest magnesium content of honey have been detected in samples from Macedonia (4.4-182.0 mg/kg) [10]. From the list of major elements the less quantified amounts can be referred to iron which have been found in Latvian honey on average $4.04 \mathrm{mg} / \mathrm{kg}(0.22-$ $21.62 \mathrm{mg} / \mathrm{kg}$ ). If compared with the literature data, Fe in honey can vary from $1.5-7.9 \mathrm{mg} / \mathrm{kg}$ in samples from Czech Republic [21] and 2.26-4.7 mg/kg [18] up to $0.3-70.4 \mathrm{mg} / \mathrm{kg}$ in samples from Slovenia [16].

Strong correlation $(>0.7)$ within major elements have been detected only between $\mathrm{K}$ and $\mathrm{Rb}$ but moderate correlation can be associated, for example between $\mathrm{Ca}$ and $\mathrm{Fe} ; \mathrm{K}$ and $\mathrm{Ca} ; \mathrm{Mg}$ and $\mathrm{K}$ or $\mathrm{Ca}$. As mentioned before major element content of honey is more subjected by the site specific natural conditions, however, lower amount of major elements can be concerned with lesser content of trace elements in honey.

\subsection{Geographical dissemination of elements in honey samples}

For assessment of geographical dissemination of elements in honey it was decided to group honey samples into sets based on the regional geological information of Latvia, as shown previously in fig. 1. In addition, this kind of arrangement is not randomly invented but can be tightly associated with historical regions of Latvia, i.e. the set B1 together with the west part of the set A historically are known as Kurzeme region, the set D together with the midland part of the set A corresponds to Zemgale region, the set B2 and the piece of the set $\mathrm{C}$ in the north of the country corresponds to Vidzeme region, the main piece of the set $\mathrm{C}$ and the set $\mathrm{B} 3$ are known as Latgale region. Taking into account specifics of these historical regions, it can be add that selected regions can be differed by the intensity of agriculture (e.g. more intensive in the sets A, B1 and D), traffic (A and B2), industrial activities (A) or cross-border influence (B3). Therefore geographical dissemination of elements in honey can be evaluated in wider context.

Comparison of trace and major element content of honey in-between selected sets revealed that only for $\mathrm{Cu}, \mathrm{Fe}, \mathrm{Mg}$ and $\mathrm{V}$ there are no substantial differences. The highest concentration of $\mathrm{As}, \mathrm{Co}, \mathrm{Cr}$ and $\mathrm{Sr}$ with significant differences from other sample sets was detected in honey from the set B3 but honey samples from the set $\mathrm{B} 2$ contained the highest amounts of $\mathrm{Al}, \mathrm{Zn}, \mathrm{Pb}$ and the most rich with $\mathrm{Ca}$. Honey from sample set $\mathrm{C}$ contained Mo significantly more but also $\mathrm{Zn}, \mathrm{Pb}$ and $\mathrm{Ca}$ were detected in heightened concentrations while this set was the only one where $\mathrm{K}$ concentration was the lowest (about 15\% lower than in other sets). $\mathrm{Ni}, \mathrm{Ba}, \mathrm{Rb}$ and $\mathrm{Na}$ amounts were the highest in honey samples from the set $\mathrm{B} 1$ as well as Mn amount was considerable in this set but honey from the set A 
contained $\mathrm{Mn}$ in the highest concentration than in any other honey sample set. Geochemical background of Latvia in details have been studied by Gilucis [21], who mentions that in Latgale, respectively, area of the sets B3 and $\mathrm{C}$, geochemical background of $\mathrm{Pb}, \mathrm{Cd}, \mathrm{Sb}, \mathrm{Ag}, \mathrm{Se}, \mathrm{As}$ and $\mathrm{S}$ concentration is lower than in other areas of Latvia but concentration of $\mathrm{Ni}, \mathrm{Co}, \mathrm{Fe}, \mathrm{La}, \mathrm{K}$ and $\mathrm{Ga}$ in Latgale and east of Vidzeme is heightened. Taking into account these interconnections the element content of honey is just slightly affected by geochemical background. More influence on element content of honey can be attributed to anthropogenic activities, such as traffic intensity, agricultural and agrochemical actions or other ways of environmental pollution.

\section{Conclusions}

Geographical dissemination of trace and major elements in honey is obvious with exception of some elements $(\mathrm{Cu}, \mathrm{Fe}, \mathrm{Mg}, \mathrm{V})$ but it is not tightly connected with geological background. The results reveal that the most variable elements between the samples sets are heavy metals ( $\mathrm{Pb}, \mathrm{Co}, \mathrm{As}, \mathrm{Cd}, \mathrm{Sr}, \mathrm{Ni})$ therefore it can be assumed that anthropogenic activities (e.g. traffic, agriculture, industry, cross-border transfer) give the most significant influence on the element content of honey. However, more detailed analysis of the results should be carried out and geographical dissemination of elements in honey should be assessed in connection with botanical origin of honey.

In overall, analytical quantification of trace and major elements gives valuable information about element sources in selected product and can be used for consumer risk and food safety assessment.

\section{Acknowledgement}

This work has been supported by the European Social Fund within the project "Support for Doctoral Studies at University of Latvia".

\section{References}

[1] Silva, L.R., Videira, R., Monteiro, A.P., Valentao, P. \& Andrade, P.B., Honey from Luso region (Portugal): physicochemical characteristics and mineral contents. Microchemical Journal, 93(1), pp. 73-77, 2009.

[2] Enrich, C., Boeykens, S., Caracciolo, N., Custo, G. \& Vazquez, C., Honey characterization by total reflection X-ray fluorescence: evaluation of environmental quality and risk for the human health. X-Ray Spectrometry, 36(4), pp. 215-220, 2007.

[3] Ajtony, Z., Bencs, L., Haraszi, R., Szigeti, J. \& Szoboszlai, N., Study on the simultaneous determination of some essential and toxic trace elements in honey by multi-element graphite furnace atomic absorption spectrometry. Talanta, 71(2), pp. 683-690, 2007. 
[4] Anklam, E., A review of the analytical methods to determine the geographical and botanical origin of honey. Food Chemistry, 63(4), pp. 549-562, 1998.

[5] Madejczyk, M. \& Baralkiewicz, D., Characterization of Polish rape and honeydew honey according to their mineral contents using ICP-MS and FAAS/AES. Analytica Chimica Acta, 617(1-2), pp. 11-17, 2008.

[6] Bogdanov, S., Haldimann, M., Luginbuhl, W. \& Gallmannm, P., Minerals in honey: environmental, geographical and botanical aspects. Journal of Apicultural Research \& Bee World, 46(4), pp. 269-275, 2007.

[7] Staniskiene, B., Matusevicius, P., Budreckiene, R. \& Sinkeviciene, I., Determination of heavy metals concentration in honey and fish using MSICP model [In Lithuanian]. Veterinarija ir Zootechnika, 39(61), pp. 6066, 2007.

[8] Pisani, A., Protano, G. \& Riccobono, F., Minor and trace elements in different honey types produced in Siena County (Italy). Food Chemistry, 107(4), pp. 1553-1560, 2008.

[9] Chudzinska, M. \& Baralkiewicz, D., Estimation of honey authenticity by multielements characteristics using inductively coupled plasma-mass spectrometry (ICP-MS) combined with chemometrics. Food \& Chemical Toxicology, 48(1), pp. 284-290, 2010.

[10] Stankovska, E., Stafilov, T. \& Sajn, R., Monitoring of trace elements in honey from the Republic of Macedonia by atomic absorption spectrometry. Environmental Monitoring \& Assessment, 142(1-3), pp. 117-126, 2008.

[11] Silici, S., Uluozlu, O. D., Tuzen, M. \& Soylak, M., Assessment of trace element levels in Rhododendron honeys of Black Sea Region, Turkey. Journal of Hazardous Materials, 156(1-3), pp. 612-618, 2008.

[12] Yarsan, E., Karacal, F., Ibrahim, I.G., Dikmen, B., Koksal, A. \& Das, Y.K., Contents of some metals in honeys from different regions in Turkey. Bulletin of Environmental Contamination \& Toxicology, 79(3), pp. 255258, 2007.

[13] Staniskiene, B., Matusevicius, P. \& Budreckiene, R., Honey as an indicator of environmental pollution. Environmental Research, Engineering and Management, 2(36), pp. 53-58, 2006.

[14] Lachman, J., Kolihova, D., Miholova, D., Kosata, J., Titera, D. \& Kult, K., Analysis of minority honey components: possible use for the evaluation of honey quality. Food Chemistry, 101(3), pp. 973-979, 2007.

[15] Ioannidou, M.D., Zachariadis, G.A., Anthemidis, A.N. \& Stratis, J.A., Direct determination of toxic trace metals in honey and sugars using inductively coupled plasma atomic emission spectrometry. Talanta, 65(1), pp. 92-97, 2005.

[16] Golob, T., Dobersek, U., Kump, P. \& Necemer, M., Determination of trace and minor elements in Slovenian honey by total reflection X-ray fluorescence spectroscopy. Food Chemistry, 91(4), pp. 593-600, 2005.

[17] Buldini, P.L., Cavalli, S., Mevoli, A. \& Sharma, J.L., Ion chromatographic and voltammetric determination of heavy and transition metals in honey. Food Chemistry, 73(4), pp. 487-495, 2001. 
[18] Frias, I., Rubio, C., Gonzalez-Iglesias, T., Gutierrez, A.J., GonzalezWeller, D. \& Hardisson, A., Metals in fresh honeys from Tenerife island, Spain. Bulletin of Environmental Contamination \& Toxicology, 80(1), pp. 30-33, 2008.

[19] Juodisius, E. \& Simoneliene, A., Trace metals and pesticide residues in honey on the Lithuanian market [In Lithuanian]. Veterinarija ir Zootechnika, 45(67), pp. 27-32, 2009.

[20] Fernandez-Torres, R., Perez-Bernal, J.L., Bello-Lopez, M.A., CallejonMochon, M., Jomenez-Sanchez, J.C. \& Guiraum-Perez, A., Mineral content and botanical origin of Spanish honeys. Talanta, 65(3), pp. 686-691, 2005.

[21] Vorlova, L. \& Celechovska, O., Activity of enzymes and trace element content in bee honey. Acta Veterinaria Brno, 71(3), pp. 375-378, 2002.

[22] Gilucis, A., Regularities of the contents and distribution of trace elements and macroelements in the upper horizons of Latvian soils [In Latvian], University of Latvia: Riga, 2007. 